\title{
SEPARATE STOCKS OF RED SNAPPER EXPLOITATION AND MANAGEMENT IN THE INDONESIAN SECTOR OF THE ARAFURA SEA
}

\author{
Badrudin and Aisyah \\ Researcher at Research Centre for Capture Fisheries, Ancol-Jakarta \\ Received September 1-2009; Received in revised form October 19-2009; Accepted October 29-2009
}

\begin{abstract}
Red snapper resources in the Arafura Sea have been effectively exploited by the industrial scale of bottom long line, fish trawl and shrimp trawl fisheries. Research activities carried out by the ACIARRCCF revealed that there were genetic similarity of the three red snapper species between the Australian and Indonesian sectors of the Arafura Sea. These findings led the Australian side to conclude that these resources belong to one unit stock and therefore should be managed collaboratively under the framework of the 'Indonesia-Australia shared snapper management plan' Based on the economic aspect this collaborative management has a wide implication that lead to some potential losses to Indonesia. Further studies on some population dynamics aspects and analysis of the available data and information two main indicators determining unit stock, the 'spawning location' and 'population parameter' were found. From the surveys carried out by the Australian the red snapper juveniles were found in the north coast of Darwin, Gove and Weipa, northern Australia, while in Indonesian side some juveniles were found in coastal area of Sape and from the fish trawl landed in Merauke. These findings indicate that the spawning location are spread over the area of the Arafura Sea and consequently the Australian red snapper stocks are fully separated from their counterpart in the Indonesian sector. From the Australian reference it was reported that the high primary productivity of the waters surrounding Australia are absence. This high fertility of the waters has led to the higher growth rate and mortality rate of the red snappers in Indonesian waters compare with their counterpart in the Australian sector. From these aspects it could definitely be concluded that the unit stock of red snappers in the two sectors of the Arafura Sea are separated. It is further stated that the Australian and Indonesian populations of red snapper provide separate mega stocks. Back to the intention of the collaborative research on red snappers stock in the Arafura Sea that; if these snappers belong to one unit stock then collaborative management for sustainable benefit would be mandatory. In case otherwise all management measures would be under respective country in accordance with their respective jurisdictions and the long-term implications of the fishery management regimes of the two countries are likely to be independent.
\end{abstract}

KEYWORDS: red snapper, stock assessment, management, Arafura Sea

\section{INTRODUCTIONS}

The shallow waters of the continental shelf of Arafura Sea provide the most productive fishing ground in Indonesia. The waters has been regularly enriched by the nutrient rich upwelling from the Banda Sea and additional nutrient from rivers originated from densely mangrove terrestrial areas of Papua. Such condition has triggered the higher productivity of the Arafura Sea that resulted in the flourishing of demersal fish population including red snappers in the Indonesian sector of the Arafura Sea. Compare with the adjacent waters of the Arafura Sea, the highest primary productivity was occurred in the southwest of the Papua (Figure 1). The Arafura Sea is part of the Sahul Shelf where the waters provide part of Indonesian Fisheries Management Area (WPP 718) while the other is part of the Australian shelf of the Arafura Sea.
In the introduction of the Australian Government policy statement explaining basic characteristics of the Australian fishing industry it is cited that primary productivity of the waters is determined by the availability of nutrient. All of the major fisheries of the world are located where the supply of nutrient is high. There are two major causes of regionally high nutrient levels. The first is a major river system which carries nutrients from the terrestrial environment into the ocean, for example the Mississippi river carries nutrients into the Gulf of Mexico. The second cause is currents raising nutrient rich waters to the surface where sunlight provides the energy for photosynthesis. The combined effect of nutrients and sunlight causes a virtual biological explosion which results in rich fisheries like those of the west coast of South America and southern Africa. Unfortunately the conditions for high nutrient level are largely absent from waters around Australia (Anonymous, 1989). 


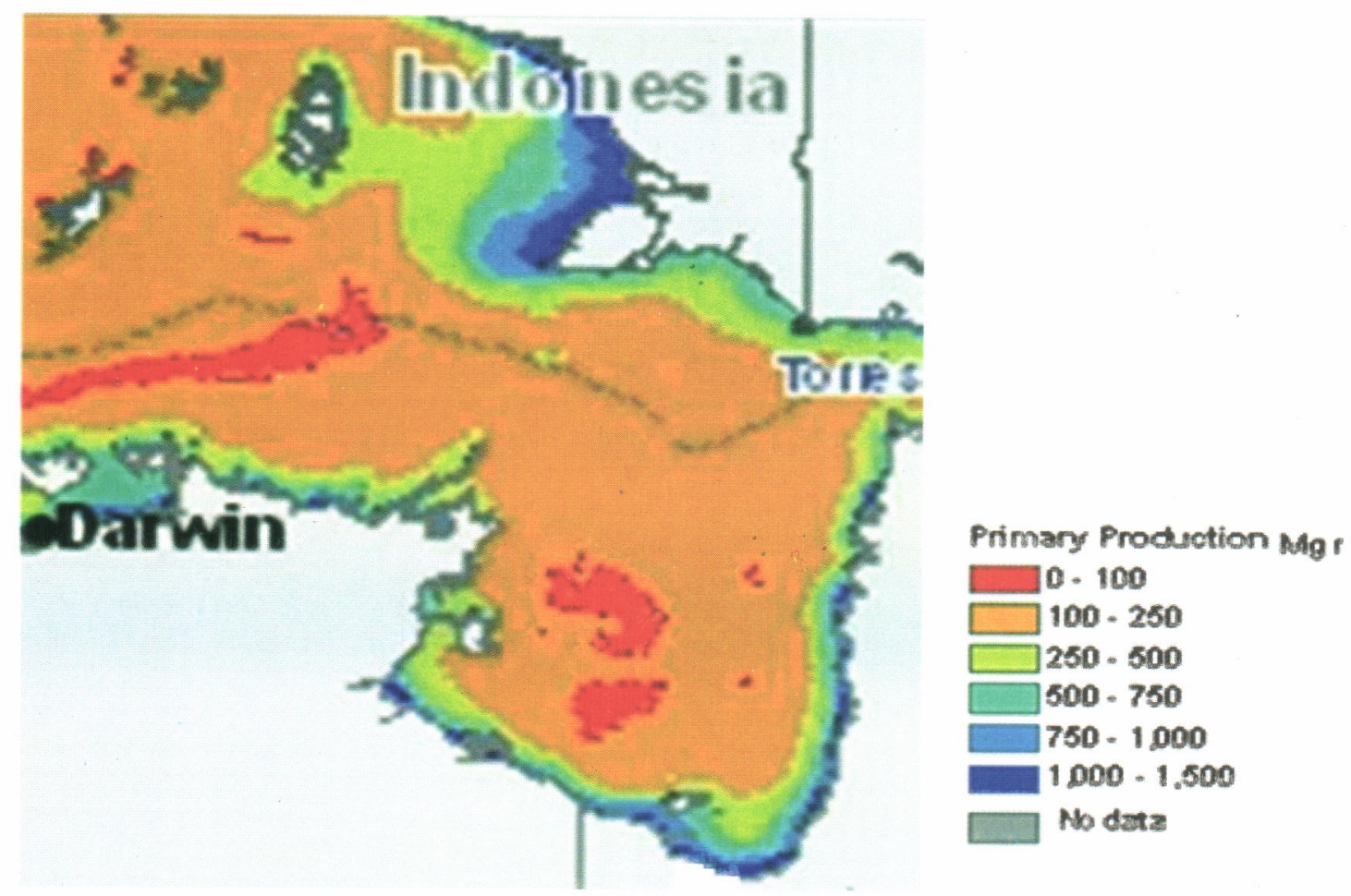

Figure 1. Distribution of primary productivity in the Arafura Sea and Gulf of Carpentaria. Source: Purwanto (2008)

The demersal fishing activities in the Arafura and the Timor Sea by the Taiwanese and Thai with the license from Darwin have been carried out since $1970^{\text {th }}$. Until 1990 the demersal fish resources in the Australian shelf of the Arafura Sea have been intensively exploited by the Japanese, Taiwanese and Thai trawlers. Information obtained includes catch composition, fishing effort and status of exploitation (Ramm \& Xiao, 1994; Ramm, 1994). The target species include red snappers (Lutjanidae), emperors (Lethrinidae), trevallies (Carangidae), and threadfin bream (Nemipteridae).

From historical records of Taiwanese catch in the AFZ (Australian Fishing Zone) the red snappers in 1988 was about 1019 tons and in the next year was drastically decreased to only 39 tons (Ramm, 1996). Due to the decreased of the catches, in 1990 the Australian demersal fisheries in the Arafura Sea was declared as fully exploited and since that time the red snappers fishing license for all fisheries was stopped (Anonymous, 1999). This situation was based on the occurring concern of over-exploitation. If the stocks are shared by the two countries, overexploitation in one sector will directly affect the stock in both sector of the Arafura Sea.

\section{MATERIALS AND METHODS}

Data and information analyzed provide part of the results obtained from the ACIAR-RCCF (Australian Center for Agricultural Research-Research Center for Capture Fisheries, Ministry of Marine Affairs and Fisheries) research cooperation during 1999-2003. A number of new additional data for up dating purposes have been collected and incorporated in the analysis especially after 2007. Catch and effort data of Tanjung Balai Karimun bottom long line have been collected from sub bases Kupang in 2007 and Probolinggo in the mid 2009. Further analysis of data and information on some biological and population dynamics aspects were carried out based on a number of internal reports, workshops and publications prepared as the output of the Australia-Indonesian research collaboration reported by Blaber et al. (2005) and Fry et al. (2009).

\section{RESULTS AND DISCUSSIONS}

\section{The Red Snappers}

Red snapper or locally called 'bambangan' is one of the most economically important and abundantly 
caught demersal fishes in Indonesia. The fish is usually caught in the continental shelf areas. Some species live in a lightly coral habitat (Talbot, 1960). All red snappers belong to the family of Lutjanidae. The term red snapper is usually applied to the fish of the lutjanid fish having color from yellowish-red to dark and blackish-red from the genera of Lutjanus and Pinjalo, which in some islands of Indonesia having specific local name. Lutjanus malabaricus in Sumbawa Besar (West Nusa Tenggara) is called as the real snapper, L. bohar, Njalu, L. sebae, Kemonca, L. argentimaculatus, Jarang gigi, and L. gibbus called Dapa, while other red snappers are called as bambangan. In the national fisheries statistics, all the red snappers belong to one group of bambangan and put in one box. A number of red snappers found in the field consisted of at least about 15 species with its different local name (Table 1).

Other species of the Lutjanidae having large size with yellowish-red and silver-reddish include Pristipomoides spp., Symphorus spp., Aprion spp., and Etelis spp., all of them are not recorded in the statistics. Pristipomoides spp., in the eastern Indonesian waters is called 'anggoli' (probably from Ang kohli, in Malaysia-Singapura). These species are often caught in the hand line fisheries in the relatively deeper waters of 200-300 m.

In line with the increasing trend of red snappers demand locally, domestic and export market, attempt in the increasing production scheme need to be supported by research activities in the field of stock assessment and methods of exploitation to obtain optimum and sustainable yield. The fish resources exploitation in the 'transboundary' area of the Indonesian EEZ of the Arafura and the Timor Seas optimally and sustainably provide some potential resources utilization to increase social welfare and to fulfill international responsibility in the framework of the strengthening the principle of Nusantara Outlook.

From the length-weight relationship equation it can be predicted the length of fish at a certain weight and vice versa. From this equation it is also possible to obtain information on the growth pattern of fish either isometric or allometric. Length-weight relationship of fish followed the equation:

$$
W=a L^{b}
$$

where:

$$
\begin{aligned}
& W=\text { weight } \\
& L=\text { length, } a \text { and } b \text { constants }
\end{aligned}
$$

If $b=3$ : isometric, while $b \neq 3$ allometric. Growth of red snapper in this context followed the von Bertalanffy growth equation:

$$
L_{t}=L_{n}\left(1-e^{-K(t-10)}\right)
$$

where:

$$
\begin{aligned}
& L_{t}=\text { length at age } t \\
& L_{n}=\text { Length infinity } \\
& K=\text { instantaneous growth rate } \\
& t_{0}=\text { theoretical age of fish at zero length }
\end{aligned}
$$

Population parameters of red snapper in both Australian and Indonesian sector of the Arafura Sea including growth rate $(\mathrm{K})$, natural mortality rate (M from Pauly in Sparre \& Venema, 1992), length infinity and the constants of length-weight relationship (' $a$ ' and ' $b$ ') were collected through references (Table 2).

Table 1.

The red snappers species in Indonesian waters

\begin{tabular}{clll}
\hline No. & \multicolumn{1}{c}{ Scientific name } & \multicolumn{1}{c}{ English name } & \multicolumn{1}{c}{ Local name } \\
\hline 1. & Lutjanus malabaricus & Malabar blood snapper & Kakap asli \\
2. & L. gibbus & Humpback red snapper & Dapa \\
3. & L. erythropterus & Crimson snapper & Bambangan \\
4. & L. bohar & Two-spot red snapper & Njalu \\
5. & L. sebae & Emperor red snapper & Kemonca \\
6. & L. argentimaculatus & Mangrove red snapper & Jarang gigi \\
7. & L. johnii & John's snapper & Jenaha \\
8. & L. bitaeniatus & Indonesian snapper & Kakap merah \\
9. & L. timorensis & Timor snapper & Kakap merah \\
10. & L. monostigma & One-spot snapper & Kakap merah \\
11. & Pinjalo pinjalo. & Pinjalo & Kakap merah \\
12. & Pristipomoides multidens & Gold-band snapper & Anggoli, Kurisi bali \\
13. & P. typus & Sharptooth jobfish & Kurisi bali \\
14. & P. filamentosus & Randall' snapper & Kurisi bali \\
15. & Etelis carbunculus & Ruby snapper & Guntur \\
\hline
\end{tabular}


Table 2

Growth parameters of red snapper L. malabaricus in the Indonesian and Australian sectors of the Arafura Sea

\begin{tabular}{cccc}
\hline Parameters & Indonesia & Australia & Unit \\
\hline K (Growth rate) & 0,8 & 0,32 & per-year \\
$M$ (Mortality rate) & 1,33793442 & 0,74938014 & per-year \\
$L_{\infty}$ & 48,6 & 45,3 & $\mathrm{~cm}$ \\
$t_{0}$ & $-3,300$ & $-1,700$ & year \\
'a' & $1,00 \mathrm{E}-05$ & $4,00 \mathrm{E}-05$ & \\
'b & 3,0269 & 2,9475 &
\end{tabular}

Sources: Blaber eí al. (2005)

From the table it is likely that the population parameters ( $K$ and $M$ ) of red snapper in Indonesian sector of the Arafura Sea differ from the same fish species in the Australian sector of the Arafura Sea. The $K$ value of the Indonesian red snapper is more than double $(>200 \%)$ compare with the Australian red snapper. Similar phenomenon is also applied with the natural mortality rate. From the constant length-weight relationship of ' $b$ ', it is appeared that the growth pattern of red snapper in Indonesian waters was isometric, while in the Australian waters was allometric. From the difference growth pattern and the value of length infinity it is likely that the red snapper in the Australian waters was 'thinner' compare with the same species in Indonesian waters. From these aspects it can be concluded that the red snapper unit stocks in Indonesian waters are separated from those snapper in the Australian waters

The ideal stock is that described by Cushing (1968) in Gulland (1983), as one that has a single spawning ground to which the adults return year after year. $A$ group of fish can be treated as a unit stock for assessment purposes if there is no difference in the value of population parameters (Guiland, 1983). If there are differences in the population parameters (growth and mortality etc.) stock separation are likely occurred. Looking at the population parameters (Table 2 ), it is likely that the red snapper stock separation occurred between the stocks in Australian and the Indonesian sectors of the Arafura Sea.

From the surveys carried out in the north Australia and Sape of the eastern Indonesia, juvenile of $L$. erythropterus and L. malabaricus were found in muddy coastal waters or at the coarse sandy substrate and lower structure such as coral rubble in the northern waters of Darwin, Gove and Weipa. Differ with the fishing survey in Sape using encircling net, in the north Australia juvenile red snapper $L$. malabaricus were caught with otter trawl. This is probably due to the differences in habitat of this species compare with $L$. erythropterus. Catch records from previous research prawn trawling studies in the Gulf of Carpentaria between 1996 and 1998 also indicated that few age-0 red snappers were caught in the deeper water commercial trawl grounds, habitats typically with muddy or silt substrate. Further work is required in determining the importance of these inshore estuarine habitats for age- 0 red snapper and in identifying the habitats of age-0 L. malabaricus within northern Australia (Fry et al., 2009). From these survey results it can be concluded that the spawning location in both Australia and Indonesia are scattered in many places and separate each other. This findings confirming that the red snapper stock available in the Australian sector is definitely separated from their counterpart living in the Indonesian sector of the Arafura Sea. The same case is also applied to the goldband snapper (Pristipomoides multidens) stock that has been reported earlier by Lloyd et al. (1996).

\section{Exploitation Level}

From the analysis of population genetic (allozyme and mitochondrial DNA) of red snapper, $L$. malabaricus, L. Erythropterus, and P. multidens, the Australian side concluded that the red snapper in the Arafura Sea provide one unit stock and therefore should be collaboratively managed by the Australia and Indonesia. Based on population parameters of the three species and with estimated biomass in 1990 as a reference point, several scenarios of biomass dynamic and annual total catch as management option have been simulated by Blaber et al. (2005) as follow.

Based on the calculation on the number of fishing vessel, trip and mean catch per-unit of effort, the optimistic scenario for the catch in Indonesian waters would be around 1,303 ton, compare with the estimated catch by the model of 1488 tons (Blaber et al., 2005). This condition would be valid if the assumption that the red snapper in the Arafura Sea as one unit stock is fulfill. However, from the results of biological and population dynamic research it was revealed that the stock of Australian red snapper is separated from its 


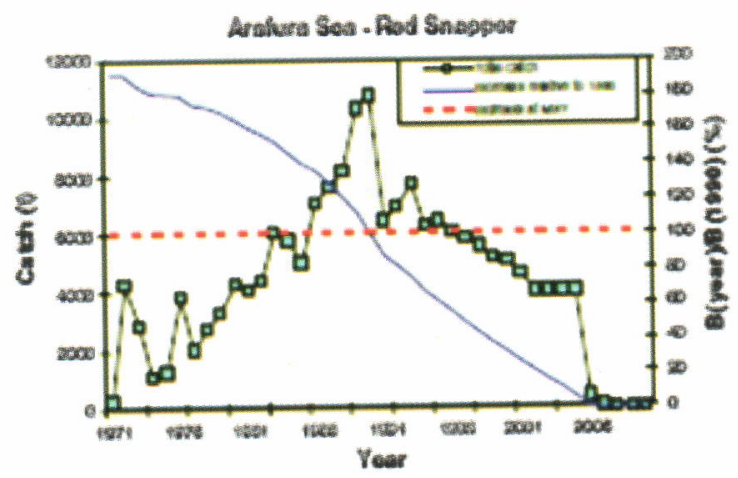

Figure 2. For the pessimistic option, catch in 2002 of 4000 tons, biomass level would be about $11 \%$ from limit reference point (biomass at 1990) and therefore the red snapper biomass collapse is underway (started from $2006 / 2007$....) especially if high catch is maintained.

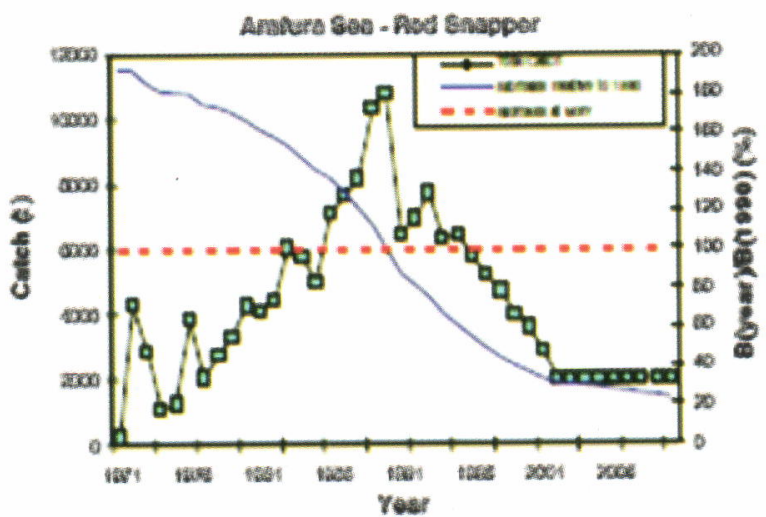

Figure 3. For the more optimistic option would be catch of 2000 tons in 2002 , where the biomass level around $31 \%$ of the biomass level in 1990. If the future catch is maintained as the present time, the decreased of red snapper biomass will be slowly and at 2010 biomass level will only $23 \%$ from the biomass level 1990.

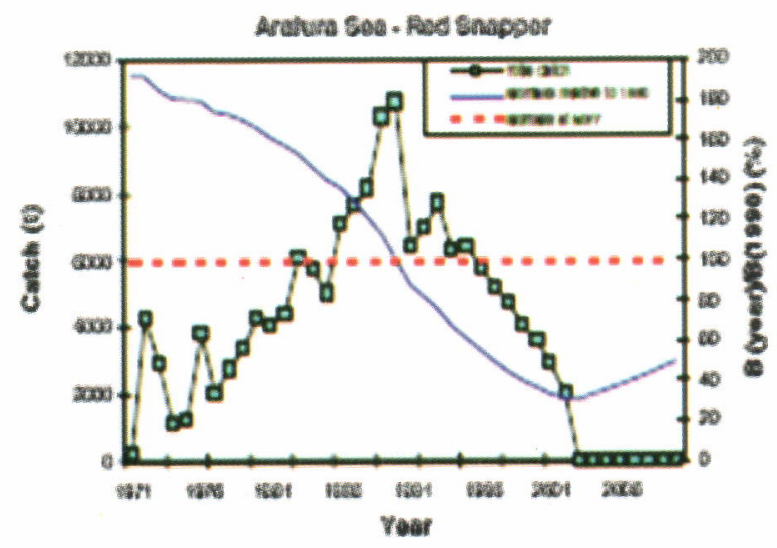

Figure 4. Even under optimistic scenario, the recovery of biomass will occur if the catch would only 1500 tons. To accelerate the biomass recovery to a level of 1990 biomass significantly would only through the closing of the fisheries for the next 10 years. 
counterpart in Indonesian sector of the Arafura Sea. With reference to the Figure 1, the statement that in $2006 / 2007$ 'collapse is underway' to the red snapper fisheries in the Arafura Sea would be too early and is likely premature. This can be confirmed with the Tanjung Balai Karimun bottom long line catches fishing in the Arafura Sea with the sub base in Kupang, where the red snapper catch was still around 1,673.5 tons (Table 3). The likely substantial amount of catches of red snapper from fish net fishery (fish trawl) landed in Merauke, Tual, and Ambon or transshipped from the catcher to the fish carrier are not included.

What is the exploitation level of the Arafura Sea red snapper fishery in 2009? From Probolinggo sub base the recorded landing of the TBK bottom long line fishing in the Arafura Sea in 2008 and until August 2009 it can be concluded that the collapse of the red snapper resource biomass will not be happening for at least for the next one or two years. The catches from the TBK bottom long line recorded by the company base in Probolinggo in 2008 was 1,672 tons and until August 2009 the cumulative catches was already 1,523 tons (Table 3). A likely substantial amount of red snapper catches landed in Tual and
Merauke from fish net fisheries and as bycatch of shrimp trawl landed in Ambon and Sorong and from the small scale fisheries landed in other places are not included. It is appeared that what is worrying by the Australian side, the collapse of the red snapper fisheries in the Arafura Sea in 2007 as scenario in Figure 1, has not been happened. This was due to the basic assumption that the red snapper stock in the Arafura Sea form one unit stock is failed. The existing spawning ground as shown by the wide spread of juvenile habitat as well as the differences in the population parameters caused by the differences in the primary productivity between the two sector of the Arafura Sea confirmed that the red snapper stock in the Australian and the Indonesian sector of the Arafura Sea is separated. This stock separation confirmed the earlier finding reported by Lloyd et al. (1996) that the golband snapper in the Australian and Indonesian waters provide are separate stocks. It is further stated that the Australian and Indonesian populations of goldband snapper provide separate mega stocks and the long-term implications of the fishery management regimes of the two countries are likely to be independent.

Table 3. Red snapper catches of TBK bottom long line in the sub bases of Kupang and Probolinggo (Unit: Ton).

\begin{tabular}{|c|c|c|c|c|c|c|}
\hline & $2007^{11}$ & & $\left.2008^{2}\right)$ & & $\left.2009^{2}\right)$ & \\
\hline & Red snappers & Other fishes & $\begin{array}{c}\text { Red } \\
\text { snappers }\end{array}$ & $\begin{array}{l}\text { Other } \\
\text { fishes }\end{array}$ & $\begin{array}{c}\text { Red } \\
\text { snappers }\end{array}$ & $\begin{array}{l}\text { Other } \\
\text { fishes }\end{array}$ \\
\hline January & 144.9 & 65.2 & - & - & 156.6 & 328.8 \\
\hline February & 25.3 & 19.1 & - & - & 9.7 & 21.8 \\
\hline March & 35.4 & 22.7 & 23.6 & 47.2 & 209.8 & 645.6 \\
\hline April & 82.9 & 43.3 & 267.6 & 490.7 & 386.2 & 719.5 \\
\hline May & 73.8 & 32.0 & 238.7 & 640.6 & 357.2 & 378.9 \\
\hline June & 75.4 & 31.8 & 184.4 & 603.6 & 237.8 & 565.3 \\
\hline July & 118.6 & 72.5 & 55.2 & 192.6 & 84.8 & 344 \\
\hline August & 279.2 & 185 & 118.1 & 443.1 & 81.2 & 263.7 \\
\hline September & 208.2 & 103 & 115.6 & 466.3 & & \\
\hline October & 231.0 & 94 & 94.3 & 618.8 & & \\
\hline November & 228.5 & 130 & 292.2 & 676.8 & & \\
\hline December & 170.3 & 99 & 288.5 & 558.9 & & \\
\hline Total & $1,673.5$ & 897.2 & $1,678.2$ & $4,738.6$ & $1,523.3$ & $3,267.6$ \\
\hline$\%$ Red snappers & 65.10 & & 26.15 & & 31.80 & \\
\hline
\end{tabular}

Notes: 1) Data collected from the TBK BLL, sub base Kupang; ${ }^{2)}$ Data collected from the TBK BLL, sub base Probolinggo; Data 2009 until August 2009 


\section{Management Option}

In the draft of 'Management Plan for the Shared Stock of Red Snappers in Australian and Indonesian Waters' (April 2007) stated that the priority of management measures for both Indonesia and Australia are as follow:

1. Ban destructive fishing gear.

2. Minimize IUU fishing practices.

3. Develop and/or maintain appropriate mechanism to control catch level.

4. Control total fishing capacity by:

a. Restricting vessel size as appropriate

b. Ensure that the mesh size of trawl nets (fish net) is at least $10 \mathrm{~cm}$ to reduce capture of prespawning individuals.

c. Limit the number of long lines and traps.

5. Determine the need for temporal and/or spatial closure to protect known nursery and 'pre-adult' grounds.

6. Replenishment closures-close all or part of the fisheries to protect mutually determine level of spawning stock biomass.

7. Habitat protection-introduce fishery management area for habitat of critical importance to red snappers.

8. Restrict trade (market controls) in fish that have not been legally caught consistent with this management plan.

9. Implement bycatch reduction devices and/or turtle exclusion devices in trawl nets.

From the aspect of conservation the nine measures are very effective, for only based on three red snapper species all the 15 species including all demersal resources of at least 100 species will inclusively be managed. Implementation of these measures are likely parallel with the principle of optimal and sustainable exploitation. Although, most fishing activities in the Arafura Sea are dominated by the industrial scale, the small scale/artisanal fishing activities can also be found in the waters around Merauke, Kai islands, Dolak, Kaimana, Tembagapura, and others that their contribution be increased ultimately in accordance with the scheme of poverty alleviation and food security (FAO, 2009).

Some of these management measures have already been implemented by the Indonesian government. Due to the limited of accurate data close area and close season have not been implemented as these will need some scientific evidence. On the other hand the availability of data and information regarding the subject are inadequate.

\section{CONCLUSIONS}

1. The red snapper resources in the Arafura Sea have been effectively exploited by the industrial scale of bottom long line, fish trawl/fish net and shrimp trawl fisheries. With the phenomena of genetic similarity of red snapper in the Arafura Sea (Indonesian and Australian sector) has push the Australian side to conclude that the red snapper in the Arafura Sea belong to one unit stock or shared stock. Therefore, the stock should collaboratively be managed under the framework 'Indonesia-Australia shared snapper management plan'. Unfortunately, this collaborative management will lead to some potential economic lost to Indonesia, as the number of fishing effort level in the two sectors are disproportioned.

2. Two main indicators for unit stock separation are considered, the differences in spawning ground and the population parameters (growth, mortality, etc.) From juvenile survey carried out in the north coast of Darwin, Gove, and Weipa in Australia and in Sape and other part of eastern Indonesia, it can be concluded that the spawning location in both Australia and Indonesia are scattered in many places and separate each other. This findings confirming that the red snapper stock available in the Australian sector is definitely separated from their counterpart living in the Indonesian sector of the Arafura Sea. The primary productivity in the Indonesian sector is much higher compare with the productivity in the Australian sector. This high productivity level has directly affected to the higher rate of growth and mortality as population parameters compare with the fish in the Australian waters

3. Back to the intention of the collaborative research on red snappers stock in the Arafura Sea that; if these snappers belong to one unit stock then collaborative management for sustainable benefit would be mandatory. In case otherwise all management measures would be under respective country in accordance with their respective jurisdictions and the long-term implications of the fishery management regimes of the two countries are likely to be independent.

\section{ACKNOWLEDGEMENTS}

This paper was prepared in the framework of research collaboration funded by the Directorate General of Higher Education of the Ministry of National Education, Indonesia in the F.Y. 2009, to whom the 
authors would like to express their gratitude. Thanks are also due to the Chairman of the Agency for Marine and Fisheries Research for the facilitations, assistances and administrative works without which this paper would not be materialized

\section{REFERENCES}

Anonymous. 1989. New directions for commonwealth fisheries management in the 1990s. Australian government publishing service Canberra. $114 \mathrm{pp}$.

Anonymous. 1999. Biology, fishery assessment, and management of shared snapper fisheries in Northern Australia and Eastern Indonesia. Project Document FIS/97/165. ACIAR. 43 pp.

Blaber, S. J. M., C. M. Dichmont, R. C. Buckworth, Badrudin, B. Sumiono, S. Nurhakim, B. Iskandar, B. Fegan, D. C. Ramm, \& J. P. Salini. 2005. Shared stocks of snappers (Lutjanidae) in Australia and Indonesia: Integrating biology, population dynamics and socio-economics to examine management scenarios. Reviews in Fish Biology and Fisheries. 15: 111-127.

FAO. 2009. The State of World Fisheries and Aquaculture 2008. FAO Fisheries and Aquaculture Department. FAO-UN. Rome. $176 \mathrm{pp}$.

Fry, G., D. A. Milton, T. Van Der Velde, I. Stobutzki, R. Andamari, Badrudin, \& B. Sumiono. 2009. Reproductive dynamics and nursery habitat preferences of two commercially important IndoPacific red snappers Lutjanus erythropterus and L. malabaricus. Fish. Sci. 75: 145-158."
Gulland, J.A. 1983. Fish Stock Assessment-A Manual of Basic Methods. John Wiley \& Sons. New York. $223 \mathrm{pp}$.

Lloyd, J., J. Ovenden, S. Newman, \& C. Keenan. 1996. Stock structure of Pristipomoides multidens resources across Northern Australia. Fish. Res. Dev.Corp. Fish. WA, NT-DPIF, QDPI. Fishery Report No.49. 36p+21p Tables. 28p App; 14p Figs.

Ramm, D. C. \& Y. Xiao. 1994. Demersal fisheries in Northern Australia. Australia's Northern Trawl Fishery. Fishery Report No.32/1994.

Ramm, D. C. 1996. Sustainable groundfish yields in the Arafura Sea. Report on a Scientific Exchange Visit to Institute of Oceanography. National Taiwan University. 6 pp.

Ramm, D. C. 1994. Estimation of biomass and fishery yield for snapper stocks in Northern Australian waters. Australia's Northern Trawl Fishery. Fishery Report No.32/1994.

Sparre, P. \& S. C.Venema. 1992. Introduction to tropical fish stock assessment. Part I. Manual. FAO Fish. Tech.Pap. 306/1. Rev. 1. FAO-UN. Rome.

Talbot, F. H. 1960. Notes on the biology of the Lutjanidae (Fisces) of the East African coast, with special reference to $L$. bohar (Forskal). Annals of the South African Museum. XLV: 549-573. 